\title{
Natural Radioactivity in Polish Coal Mines: An Attempt to Assess the Trend of Radium Release into the Environment
}

\author{
Małgorzata Wysocka ${ }^{1}$ (D) Stanisław Chałupnik ${ }^{1}$. Izabela Chmielewska ${ }^{1}$ Ewa Janson ${ }^{1} \cdot$ Wiktor Radziejowski $^{1}$. \\ Krzysztof Samolej ${ }^{1}$
}

Received: 16 October 2018 / Accepted: 1 August 2019 / Published online: 9 August 2019

(c) The Author(s) 2019

\begin{abstract}
The highly mineralised formation waters in the coal mines of Poland's Upper Silesian Coal Basin contain natural radioactive nuclides, mostly radium. The ${ }^{226} \mathrm{Ra}$ concentration in the groundwater that flows into the underground mine workings reaches $390 \mathrm{~Bq} / \mathrm{L}$, and is sometimes exceeded by the ${ }^{228} \mathrm{Ra}$ concentration. The radium-bearing water sometimes also contain barium ions, which enables coprecipitation of barium-radium sulphate. Another type of radium-bearing water contains sulphate ions instead of barium; in this case, radium is transported to settling ponds and downstream. We have assessed the daily activity of radium in waters flowing into the underground mines and being discharged to the environment. Based on 1995 data, we estimate that the total activity of radium isotopes flowing into the mines was about $1300 \mathrm{MBq} / \mathrm{day}$, while the radium activity in the discharge waters was about $700 \mathrm{MBq} /$ day. A similar assessment performed with 2016 data indicated that the total activity in inflows was roughly $1150 \mathrm{MBq} /$ day, while that discharged to surface waters was about $450 \mathrm{MBq} /$ day.
\end{abstract}

Keywords Coal mining $\cdot$ Formation waters $\cdot$ Radium inflows $\cdot$ Bottom sediments $\cdot$ Radium balance

\section{Introduction}

One of the most serious problems faced by the collieries in Upper Silesia, Poland, are the highly saline waters in the carboniferous strata (Różkowski 1995; Różkowski and Wilk 1982). These formation waters often contain elevated concentrations of natural radionuclides, which are mainly radium isotopes. Upper Silesian radium-bearing waters were first described by Sałdan (1965) and later investigated by Tomza and Lebecka (1981). The predominant radionuclides in these waters are radium ${ }^{226} \mathrm{Ra}$, a member of the uranium series, and radium ${ }^{228} \mathrm{Ra}$, a member of the thorium series. The ${ }^{226} \mathrm{Ra}$ concentration in the Upper Silesian brines is usually between 0.1 and $8 \mathrm{~Bq} / \mathrm{L}$, while ${ }^{228} \mathrm{Ra}$ concentrations usually range from 0.1 to $10 \mathrm{~Bq} / \mathrm{L}$.

Natural waters with similar high radium concentrations have been observed elsewhere (Gucało 1964), especially in oil fields (Alley et al. 2011; Eriksen et al. 2009). Hot springs in Iran contained up to $330 \mathrm{~Bq} / \mathrm{L}$ of ${ }^{226} \mathrm{Ra}$ (Khademi et al.

Małgorzata Wysocka

mwysocka@gig.eu

1 Główny Instytut Górnictwa, Katowice, Poland
1980; Sohrabi 1993). In German coal mines (Centeno et al. 2004; Eggeling et al. 2013; Gans et al. 1981), radium-bearing waters were identified with ${ }^{226} \mathrm{Ra}$ concentrations reaching $63 \mathrm{~Bq} / \mathrm{L}$. Galhardi and Bonotto (2017) described radium and uranium measurements upstream and downstream of the discharge from the coal mine, and used the activity ratios of ${ }^{234} \mathrm{U} /{ }^{238} \mathrm{U}$ and ${ }^{226} \mathrm{Ra} /{ }^{238} \mathrm{U}$ to explain the possible leaching of radionuclides from mine tailings. Although several publications have studied elevated ${ }^{226} \mathrm{Ra}$ concentrations in water, there is little information about radium isotopes from the thorium series $\left({ }^{228} \mathrm{Ra}\right.$ and $\left.{ }^{224} \mathrm{Ra}\right)$, as they are more difficult to measure (Eriksen et al. 2009; Dickson 1990; Gans et al. 1981).

Daily ${ }^{226} \mathrm{Ra}$ activity in water flowing into underground galleries and discharging from collieries was first estimated in 1987. Since then, the daily release of radium isotopes has been assessed regularly by monitoring radium concentrations in formation waters flowing into underground workings, and in the waters that then discharge to the natural environment. However, only rough estimates were made for individual or groups of mines (Chałupnik et al. 2017). Detailed analyses of radium concentrations in formation waters at all mine levels have not been conducted. 
More precise analysis of radium in underground waters became necessary in 1995, when approximately half of the mines that were still active were closed. Some of these collieries were allowed to flood, but waters from others are pumped to the surface directly or through active mines' dewatering systems (Bukowski 2015). Furthermore, we expect that more mines will be shut down or combined in the forthcoming years. Some coal mines have already or will begin to exploit deeper levels, up to $1100-1200 \mathrm{~m}$ below the surface (Dubiński 2013). We expect that radium will appear in inflows of more saturated brines at deeper levels, although we do not expect significant changes in redox potential (Gzyl et al. 2017).

\section{Brines in the Upper Silesian Coal Basin Collieries}

\section{Investigation Site}

The Upper Silesian Coal Basin (USCB) is located in the southern part of Poland (Fig. 1). There are currently 31 underground coal mines in this region extracting $\approx 72 \times 10^{6}$ metric tons (t) of coal per year. In 1995, 66 coal mines operated in the area, extracting $\approx 150 \times 10^{6} \mathrm{t}$ per year. The geological structure of Upper Silesia is very complicated, with numerous faults and other tectonic dislocations (Kotas 1982); see Fig. 2. The geological cross-section of the USCB is shown in Table 1.

There are two hydrological regions in the USCB. The first is located in the southwestern area of the basin, with

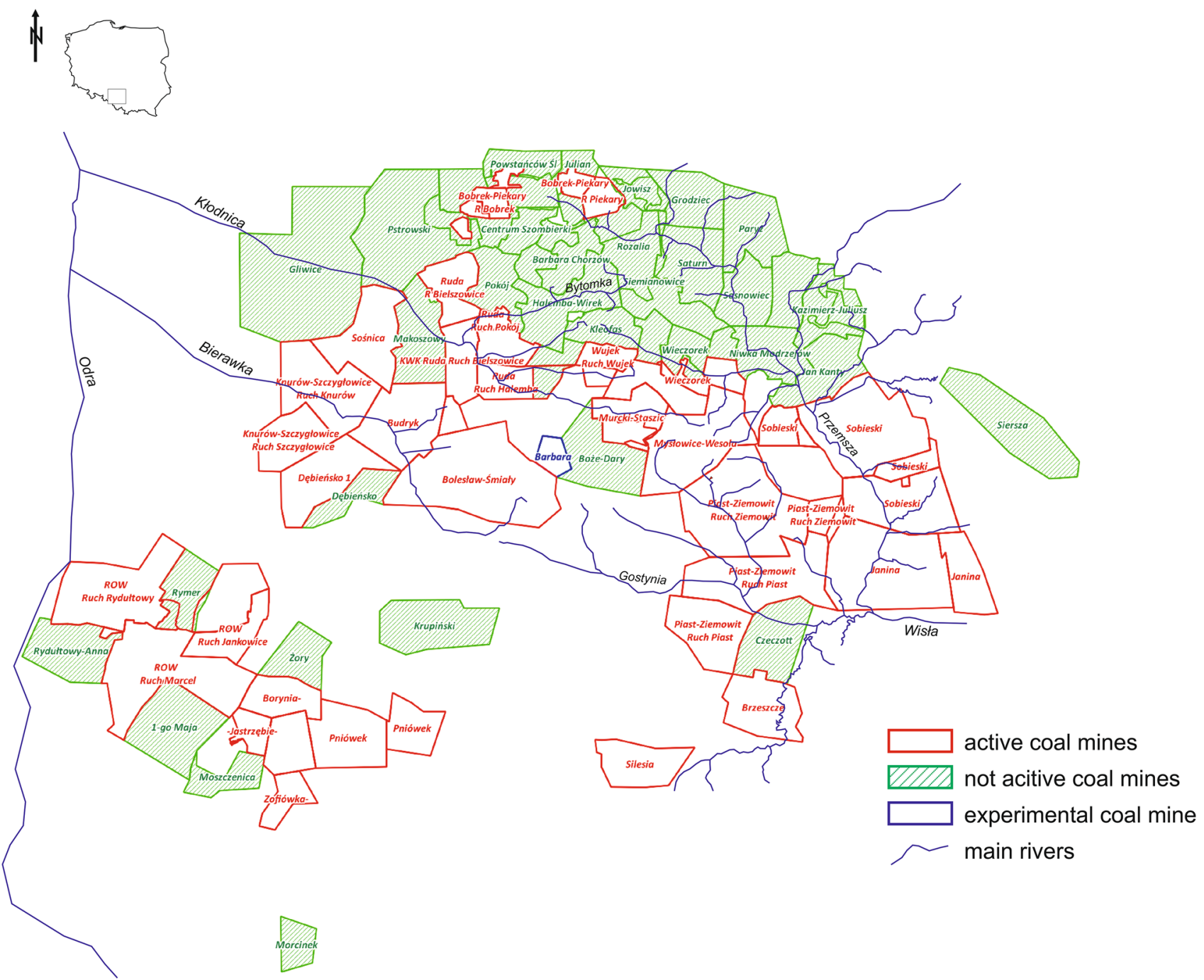

Fig. 1 Abandoned and active coal mines in the Upper Silesian Coal Basin 


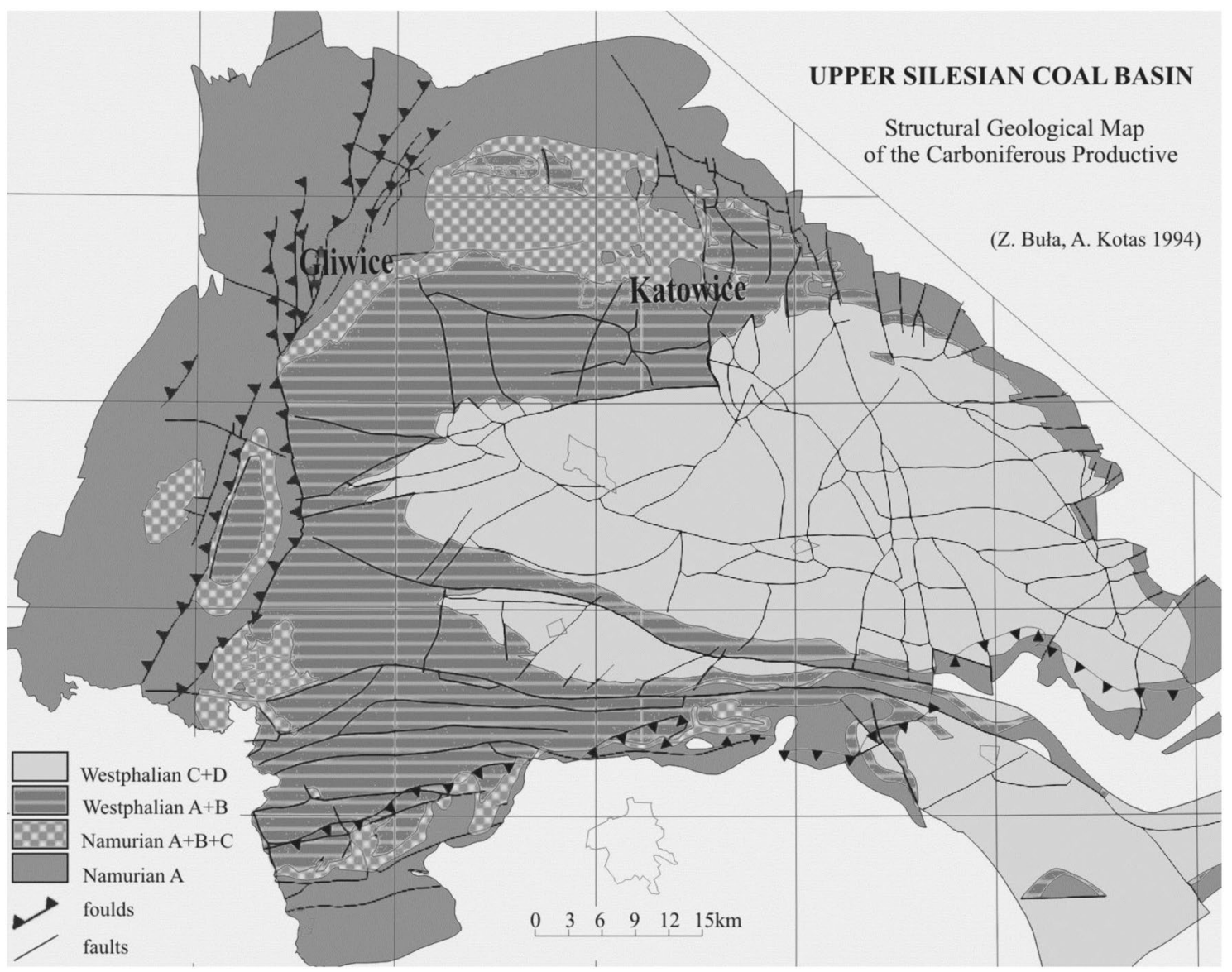

Fig. 2 Tectonic structural map of Carboniferous (based on Buła and Kotas 1994)

Table 1 Stratigraphical classification of the Carboniferous of the Upper Silesian Coal Basin (based on Buła and Kotas 1994)

\begin{tabular}{|c|c|c|c|c|c|}
\hline \multicolumn{2}{|c|}{ Namurian } & \multicolumn{4}{|c|}{ Westphalian } \\
\hline$>$ & a & $>$ & $\sigma$ & $\Omega$ & $\theta$ \\
\hline Paralic coal-bearing & \multicolumn{5}{|c|}{ Limnic coal-bearing formation } \\
\hline $\begin{array}{c}\text { Paralic Series = Marginal } \\
\text { Beds }\end{array}$ & $\begin{array}{c}\text { Upper } \\
\text { Silesian } \\
\text { Sandstone }\end{array}$ & $\begin{array}{l}\text { Mudstone } \\
\text { Series }\end{array}$ & & & \\
\hline
\end{tabular}

thick strata of impermeable sediments covering a Carboniferous formation. This overburden (700 m thick) mainly consists of Miocene clays and shales, which render water and gas migration almost impossible.

There are no Miocene clays in the second region. Carboniferous strata are covered by slightly compacted Mesozoic and Quaternary sediments. Meteoric waters, rich in oxygen, can easily reach exploitation zones. Strongly fissured Permian or Triassic limestones are the oldest formations in this area. There are several outcrops of coal seams, enabling easy migration of water and gases. The active and abandoned mines are shown in Fig. 1. Most of the mines in the northern part of the USCB are closed, but due to their interconnectivity, most of them must still be dewatered.

\section{Characteristics of Formation Waters in USCB Collieries}

The USCB mine waters contain extremely high concentrations of salts (much higher than oceanic levels), and are 
sometimes almost fully saturated. The USCB radium-bearing waters are highly mineralised $\mathrm{Cl}-\mathrm{Na}$ or $\mathrm{Cl}-\mathrm{Na}-\mathrm{Ca}$ brines. The total dissolved concentration is often $\approx 100,000 \mathrm{mg} / \mathrm{L}$, but may reach $\approx 220,000 \mathrm{mg} / \mathrm{L}$ (Różkowski 1995). The dominant anion is $\mathrm{Cl}^{-}$, which typically does not exceed $100,000 \mathrm{mg} / \mathrm{L}$, while the concentration of $\mathrm{HCO}_{3}$ reaches $10 \mathrm{mg} / \mathrm{L}$ (Bondaruk et al. 2015). Although the dominant cation is $\mathrm{Na}^{+}$(up to $50,000 \mathrm{mg} / \mathrm{L}$ ), there are significant concentrations of $\mathrm{Ca}^{2+}$ and $\mathrm{Mg}^{2+}$ (up to 10,000 and $7000 \mathrm{mg} / \mathrm{L}$, respectively). Such brines in Silesian collieries contain elevated concentrations of ${ }^{226} \mathrm{Ra}$ and ${ }^{228} \mathrm{Ra}$, and it has been confirmed that the radium content is correlated with the mine water salinity. We observed ${ }^{226} \mathrm{Ra}$ concentrations in water flowing out from rocks ranging from $<0.002$ to $390 \mathrm{~Bq} / \mathrm{L}$. While the ${ }^{228} \mathrm{Ra}$ concentrations were sometimes lower, the ${ }^{228} \mathrm{Ra}$ concentrations can exceed that of ${ }^{226} \mathrm{Ra}$ by three times or more (Chałupnik 2007; Wysocka et al. 1998). A similar effect has been observed even in drinking water supplies in Finland, where due to increased salinity near the seashore, radium concentrations were higher there than in inland water supplies (Vesterbacka 2007).

Two types of radium-bearing brine can be distinguished (Tomza et al. 1985)

- Barium-rich water: contains almost no $\mathrm{SO}_{4}{ }^{2-}$ ions, but $\mathrm{Ba}^{2+}$ ions are present at relatively high concentrations (up to $6000 \mathrm{mg} / \mathrm{L}$ ) —not often observed in nature, except in mines;

- Sulphate-rich water: $\mathrm{Ba}^{2+}$ ions do not occur in these salty waters, but there are $\mathrm{SO}_{4}{ }^{2-}$ ions at maximum total concentrations of $5000 \mathrm{mg} / \mathrm{L}$.

Although some believe that redox potential is the most important factor affecting radium appearance and behaviour in underground aquifers (Wiegand and Feige 2002) and leaching of radium from rocks, our modelling of radium behaviour (Chałupnik 2008) shows that the only process responsible for radium release into brines is the recoil effect, as was found by others (Dickson 1990; Krishnaswami et al. 1982). Radium activity is further controlled by the salinity of the brines and the presence of barium. Barium can efficiently block the cation exchange centres and prevent radium adsorption. In sulphate-rich brines, sodium (a univalent ion) is not so efficient and there is radium adsorption. This leads to a different activity ratio $\left({ }^{226} \mathrm{Ra}\right.$ and $\left.{ }^{228} \mathrm{Ra}\right)$ in barium- and sulphate-rich brines, being $2: 1$ in the first type of waters, but $1: 2$ or even $1: 3$ in the latter one., despite the $1: 1$ activity ratio of ${ }^{238} \mathrm{U}$ and ${ }^{232} \mathrm{Th}$ in the strata (Krishnaswami and Turekian 1982).

The presence of barium ions greatly influences the behaviour of radium in the environment because it enables the coprecipitation of radium and barium sulphates. Therefore, the radium present in barium-rich water always precipitates, forming radioactive deposits of radio-barite $\left(\mathrm{BaSO}_{4}+\mathrm{RaSO}_{4}\right)($ Martin and Akber 1999; Paschoa and Nobrega 1981; Tomza and Lebecka 1981; Wiegand and Feige 2002). This process can occur due to the spontaneous mixing of natural waters from different aquifers, controlled radium and barium removal, pyrite oxidation and release of sulphate ions, or even underground leaching of fly ash and sulphate from backfilled materials (Chałupnik et al. 2001). Precipitation usually occurs in the underground workings, but sometimes takes place in pipelines transporting water to the surface or in streams, small rivers, or main rivers on the surface (Bondaruk et al. 2015). In the early 1990s, we estimated that $20 \%$ of the Polish coal mines (11 collieries) contained barium-rich water. Recent assessments showed that barium-rich waters occur in $\approx 10 \%$ of the collieries (only 4 mines). The changes in the chemical composition of the formation waters are due to differing geology as mining depths have increased in the active mines and inflows of barium-rich waters in some of the mines that have closed (Chałupnik et al. 2016).

Radium-rich waters without barium ions are common in the mines in the northern and central areas of the USCB. The hydraulic conductivity of the overburden is relatively high due to the high intergranular and fissure porosity. The permeability of overlying dolomite and limestone is enhanced due to the effects of historical mining and karstic development. Water conditions in the coal measures are determined by the geological structure of the coal basin and anthropogenic factors. The most important factor is the drainage of water through the mine workings (Różkowski 1995; Wagner 1996). Sulphate rich brines are also present in mines with barium and radium-bearing waters. Both types of aquifers are interlaced and mixing of both types of waters leads to spontaneous coprecipitation of sediments with high radium content (Tomza and Lebecka 1981).

The characteristics of Upper Silesian radium-bearing waters are given in Table 2 which is based on the database of the Silesian Centre of Environmental Radioactivity in the Central Mining Institute. The highest radium concentrations are observed in barium and radium-bearing waters, where ${ }^{226} \mathrm{Ra}$ concentrations typically exceed $6.5 \mathrm{~Bq} / \mathrm{L}$ and sometimes exceed $100 \mathrm{~Bq} / \mathrm{L}$. In barium-rich waters, ${ }^{226} \mathrm{Ra}$ concentrations are always higher than ${ }^{228} \mathrm{Ra}$. In sulphate-rich waters, the predominant radium isotope is the thorium-series ${ }^{228} \mathrm{Ra}$. However, the concentrations of both radium isotopes in the latter type of waters are significantly lower and have not exceeded $12 \mathrm{~Bq} / \mathrm{L}$ in recent years, although they previously reached $20 \mathrm{~Bq} / \mathrm{L}$ (Chałupnik 2007).

The assessment of the daily activity of radium isotopes in waters flowing into underground mine galleries is not very precise due to the reasons described earlier. Water inflows with different salinities, flow rates, chemical compositions, and radium concentrations often enter the same mine. It is 


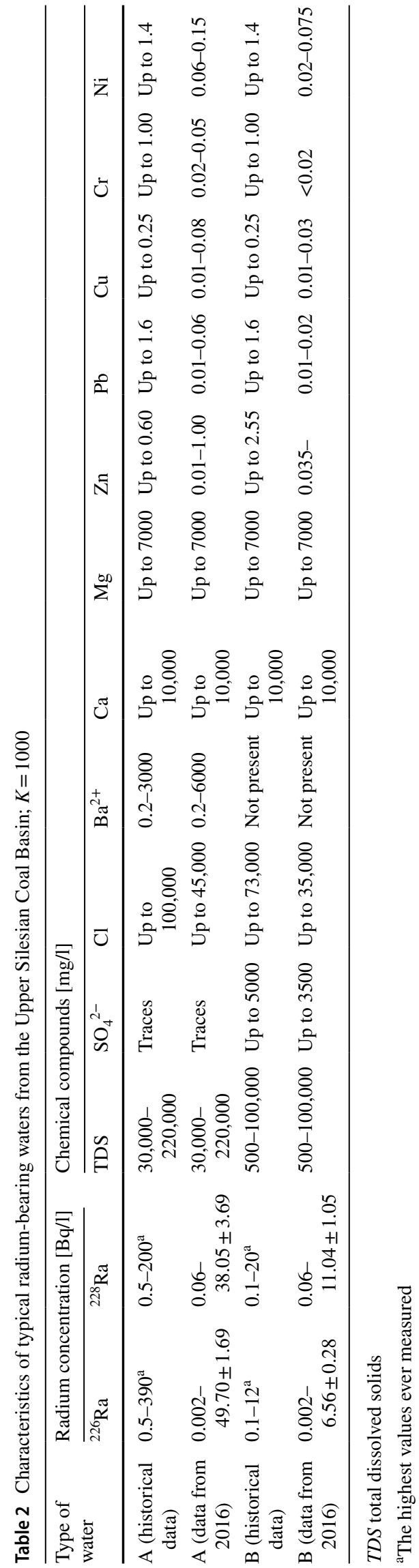

especially difficult to assess daily activity in mines where barium-rich and sulphate-rich water flow into the same mine, as spontaneous coprecipitation of radium and barium sulphates occurs immediately after the different waters mix underground. Nonetheless, even a rough approximation provides a better understanding of the scale of the problem.

\section{Methods}

\section{Sampling}

Water samples were collected by the mining staff during routine underground and surface monitoring, as required by Polish regulations. Chemical and radiological analyses were conducted to measure the concentrations of radium isotopes and other particular ions. Water directly flows into the underground workings from rocks or from boreholes, and the water pumped out from specific mining levels were also sampled in all mines. Radiochemical analyses were conducted by the Central Mining Institute.

Routinely, inflows into the underground workings are sampled once per year, and in mines with radium concentrations above $1 \mathrm{~Bq} / \mathrm{L}$, sampling is conducted more frequently. The flow rates are estimated in situ and therefore are not very precise. The level of uncertainty for the flow rate assessment of the inflows from the strata was usually between 15 and $30 \%$, accordingly to data from mines. Assessments of the flow rates from particular horizons in the coal mines were more precise, as the volume of released waters is determined using the flow rate meters of pumps. Therefore, the uncertainty of radium activity in outflowing waters is mostly due to the uncertainty of radium activity concentration measurements (8\% for ${ }^{226} \mathrm{Ra}$ and $15 \%$ for ${ }^{228} \mathrm{Ra}$ ). The surface settling ponds and downgradient brooks and rivers were routinely sampled once a year. Mines with effluent radium concentrations exceeding $1 \mathrm{~Bq} / \mathrm{L}$ were sampled four times a year. However, assessments of radium activity in surface waters is hampered because flow rates in rivers are usually unstable. The latter values were obtained from the subtraction of radium activity in outflows from the total radium activity in inflows.

\section{Determination of Radium Isotopes}

${ }^{226} \mathrm{Ra}$ and ${ }^{228} \mathrm{Ra}$ were determined by liquid scintillation counting after chemical separation of $\mathrm{RaSO}_{4}$ as a barium carrier, following the method developed by Chałupnik and Lebecka (1993). This method allows the simultaneous determination of ${ }^{226} \mathrm{Ra}$ and ${ }^{228} \mathrm{Ra} .{ }^{228} \mathrm{Ra}$ is determined by direct measurements of the low-energy beta particles it emits, while ${ }^{226} \mathrm{Ra}$ is determined by measuring the alpha particles that this radionuclide and its daughter products emit. As the 
beta spectrum is continuous, beta particles emitted by ${ }^{226} \mathrm{Ra}$ daughter products are measured in the same energy range as ${ }^{228} \mathrm{Ra}$. Therefore, this effect must be corrected for. The lower limit of detection (LLD) for ${ }^{226} \mathrm{Ra}(0.002 \mathrm{~Bq} / \mathrm{L})$ is achieved when a low background liquid scintillation spectrometer QUANTULUS model 1220, Packard Company, is used to analyse the initial $1 \mathrm{~L}$ sample, with a counting time of $1 \mathrm{~h}$. The corresponding LLD value for ${ }^{228} \mathrm{Ra}$ is approximately $0.004 \mathrm{~Bq} / \mathrm{L}$.

The analyses of natural radionuclides in deposits have been done using low background gamma spectrometry. Sediment samples were dried, pulverized, and homogenized; after that, $0.6 \mathrm{~L}$ of the final sample was placed in the Marinelli beaker and measured by high resolution gamma spectrometry. The detection limit for radium isotopes was less than $1 \mathrm{~Bq} / \mathrm{kg}$ (Michalik 2008).

\section{Results}

The main goal of our investigations was to estimate the changes of radium activity in inflows into the USCB collieries as well as in discharges from these mines. To prepare such a balance, two data sets were necessary: the flow rates and radium concentrations. The flow rate(s) of each significant inflow into mine workings and the volumes of water pumped daily to the surface from mines were obtained from every mine, together with water samples. The radium activity balance in the inflows is a sum of products, resulting from multiplication of daily water volumes and radium isotopes concentrations in every investigated inflow. The same procedure was applied for the discharge waters.

As mentioned earlier, the total activity of radium in deposits is the result of subtracting the activity values for the effluents from that of the inflows. Only general water volume data are presented here for the USCB collieries, which changed over time due to the restructuring of the Polish mining industry. For example, in the early 1990s, the total daily inflow of water was $\approx 850,000 \mathrm{~m}^{3}$. The volume of inflowing water gradually decreased to $\approx 700,000 \mathrm{~m}^{3}$ per day in 1999 . In 2010 , the total daily inflow of natural water into mines was $657,500 \mathrm{~m}^{3}$, of which $35 \%$ (almost $230,000 \mathrm{~m}^{3}$ per day) was pumped from abandoned mines (Bukowski 2015). According to our 2016 assessment, the total daily inflow of water into mines reached $\approx 630,000 \mathrm{~m}^{3}$. Closing the mines not only caused a decrease in the influent water, but also a change in the water's chemical composition. For example, according to Bukowski and Augustyniak (2013), the total release of chloride and sulphate ions decreased from $8000 \mathrm{t}$ per day in 1991 to $5000 \mathrm{t}$ per day in 2010. We also observed changes in the total activity of radium entering Silesian mines daily in the same period.

The results of the assessment conducted in 1995 showed that the approximate amount of ${ }^{226} \mathrm{Ra}$ in water flowing into the USCB coal mines reached $625 \mathrm{MBq} /$ day $(230 \mathrm{GBq}$ per year), while that of the ${ }^{228} \mathrm{Ra}$ was $\approx 700 \mathrm{MBq} / \mathrm{day}$ (255 GBq per year). Although radium concentrations in sulphate-rich waters were usually less than in barium-rich waters, the total activity of radium in inflows to mines with sulphate-rich radium-bearing waters was much greater (Skowronek et al. 1998; Wysocka et al. 2017). It should be pointed out that significant concentrations of radium isotopes in waters can only be found in active mines; in closed mines, the mixing of inflows from different aquifers causes the concentration of radium isotopes to not exceed $0,5 \mathrm{~Bq} / \mathrm{L}$. Moreover, the daily volume of dewatering is typically much less in abandoned mines than in active mines.

The calculated daily radium activity of mine inflows in 2016 differed from that calculated for 1995; the approximate calculated amount of ${ }^{226} \mathrm{Ra}$ in water flowing into coal mines in the USCB reached $483 \mathrm{MBq} /$ day $(176 \mathrm{GBq}$ per year), and $715 \mathrm{MBq} /$ day (260 GBq per year) for ${ }^{228} \mathrm{Ra}$. Comparing the assessments, the daily activity of ${ }^{226} \mathrm{Ra}$ in inflows was less in 2016 than in 1995, while the activity of ${ }^{228} \mathrm{Ra}$ was comparable. The reasons for the changes in the formation waters are complex. The most important are:

- Several coal mines in which barium-rich waters with elevated concentrations of ${ }^{226} \mathrm{Ra}$ were closed;

- An increase in the inflows of water with higher concentrations of ${ }^{228} \mathrm{Ra}$ than of ${ }^{226} \mathrm{Ra}$ (by a factor of approximately 2) was observed in the three coal mines that are the most important contributors to the daily release of ${ }^{228} \mathrm{Ra}$;

- Deepening of the exploitation level allowed access to new coal seams where formation waters with elevated radium concentrations occur. The best example is that the radium level in one of the collieries prior to 2010 did not exceed $0.2 \mathrm{~Bq} / \mathrm{L}$, but as a result of exploitation at the deeper horizon, the radium activity in inflowing waters increased to 5-7 $\mathrm{Bq} / \mathrm{L}$, while the radium content in the discharge waters was 1.5-2.5 Bq/L (Skowronek et al. 1998; Wysocka et al. 2017).

- A reduction in radium removal from underground installation water due to technical and economic problems.

The highest inflow of ${ }^{226} \mathrm{Ra}$ and ${ }^{228} \mathrm{Ra}$ isotopes to collieries with sulphate-rich waters was approximately $245 \mathrm{MBq} /$ day (80 MBq/day of ${ }^{226} \mathrm{Ra}$ and $145 \mathrm{MBq}$ /day of ${ }^{228} \mathrm{Ra}$ ). For collieries with barium-rich waters, the corresponding activity was $225 \mathrm{MBq} /$ day $\left(150 \mathrm{MBq} /\right.$ day of ${ }^{226} \mathrm{Ra}$ and $75 \mathrm{MBq} /$ day of ${ }^{228} \mathrm{Ra}$ ). The total daily inflow of water into collieries with sulphate-rich waters was $\approx 3.5$ times higher than that to collieries with inflows of barium-rich waters.

The daily activity of radium isotopes in inflows and discharge from mines for 1995 and 2016 are compared in Fig. 3. 


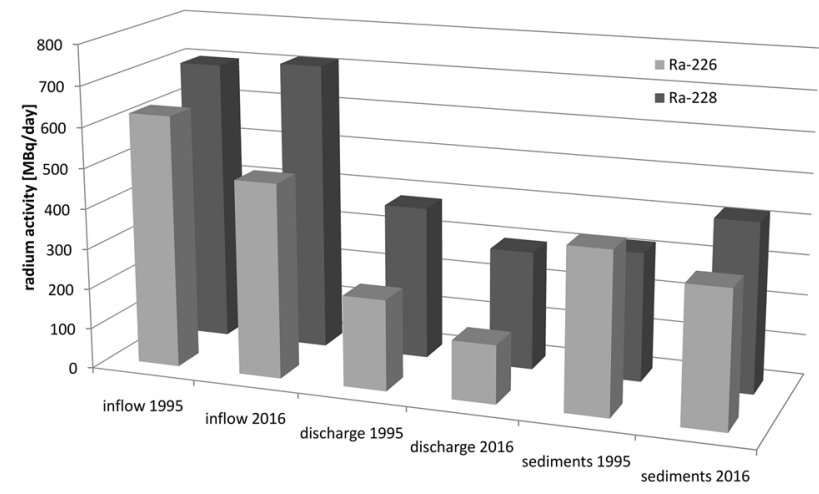

Fig. 3 Comparison of the assessments of the daily activity of radium isotope inflows to coal mines, in discharge waters and sediments in 1995 and $2016[\mathrm{MBq} / \mathrm{day}]$

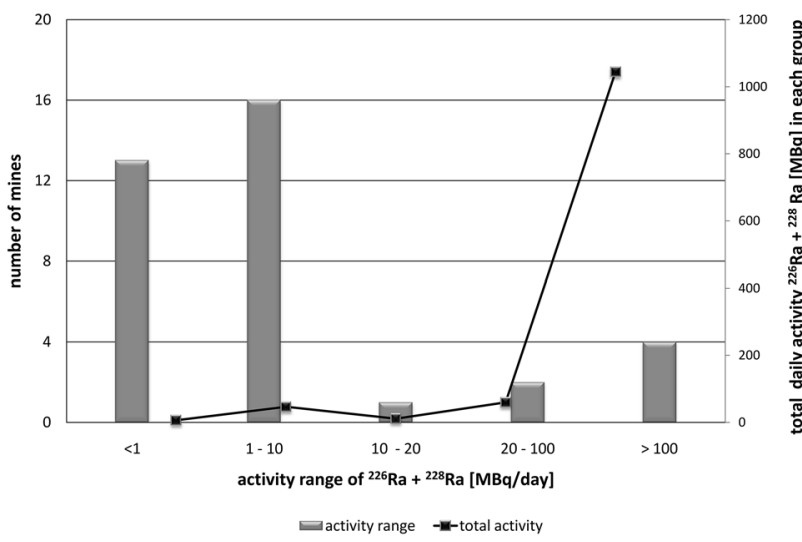

Fig. 4 Distribution of the daily activity of radium ${ }^{226} \mathrm{Ra}+{ }^{228} \mathrm{Ra}$ in water flowing into coal mines and total radium activity within each group of coal mine

Additionally, we compared the activities of the radium in water flowing into mines to the activities of radium in water discharged from coal mines to the environment.

Radium accumulates in sediments due to the coprecipitation of barium and radium sulphates and adsorption of radium to bottom sediments. We assumed that the difference between the daily activity of radium in inflows and discharges were a rough estimate of the radium activity in the sediments remaining underground. It is not possible to prove this though, as deposition typically takes place in exploited zones in an uncontrolled way.

The distribution of the ${ }^{226} \mathrm{Ra}$ and ${ }^{228} \mathrm{Ra}$ activities in water flowing into the mines is shown in Fig. 4. In most of the coal mines, the daily radium activity in the inflowing water ranges from 1 to $10 \mathrm{MBq}$. In the second-largest group of mines, daily radium activity $\leq 1 \mathrm{MBq}$. However, in four mines, the daily activity of radium in the inflows $>100 \mathrm{MBq}$. There are thus large differences in the total radium activity within the groups. The lowest total activity for one of the colliery groups equals $6.4 \mathrm{MBq} / \mathrm{day}$, while the highest one exceeds $1000 \mathrm{MBq} /$ day. The contribution of radium activity from these four mines is thus a crucial part of the radium activity in mine waters. Surprisingly, the radium concentrations in the water of those mines is not that high (reaching $\approx 17 \mathrm{~Bq} / \mathrm{L}$ of ${ }^{226} \mathrm{Ra}$ and ${ }^{228} \mathrm{Ra}$ ), but the volume of inflowing formation water is significant, reaching $30,000 \mathrm{~m}^{3} /$ day. This is much higher than that observed in the other coal mines, and the impact of these waters is responsible for approximately $92 \%$ of the total daily radium activity release in the entire USCB. However, the highest concentration of radium isotopes in underground inflows $(49.70 \pm 1.69 \mathrm{~Bq} / \mathrm{L}$ of ${ }^{226} \mathrm{Ra}$ and $38.05 \pm 3.69 \mathrm{~Bq} / \mathrm{L}$ of ${ }^{228} \mathrm{Ra}$ ) was measured as seepage from rocks in 2016.

Environmental pollution caused by the release of radium with the brine from the coal mines is an important issue. The radium (450 MBq/day in 2016) being discharged with mine effluents into surface settling ponds, which are only designed to remove suspended material, is significant, and adsorption of radium to the sediment in these ponds only removes a small portion of the radium activity $(5-10 \%)$. The remaining activity is released downstream into streams and rivers with the brine, where the radium concentrations gradually decrease due to dilution and slow radium adsorption to the bottom sediments. Elevated radium concentrations, up to $0.05 \mathrm{~Bq} / \mathrm{L}$ can be seen as far as $100 \mathrm{~km}$ downstream from discharge points, as the typical radium concentration in surface and river waters do not exceed $0.008 \mathrm{~Bq} / \mathrm{L}$ (Koster et al. 1992; Wardaszko et al. 2001). This process leads to the creation of deposits with radium concentrations that often exceed $1 \mathrm{~Bq} / \mathrm{g}$.

The typical concentrations of ${ }^{226} \mathrm{Ra}$ and ${ }^{228} \mathrm{Ra}$ in the USCB soils are similar to the world average $(25 \mathrm{~Bq} / \mathrm{kg}$ for both nuclides), while their concentrations in the strata adjacent to the coal seams do not exceed $120 \mathrm{~Bq} / \mathrm{kg}$ and $100 \mathrm{~Bq} /$ kg, respectively (Michalik 2005; Wysocka and Skowronek 1991). This value has been established as the "exemption level" in the Euratom/59/2013 EU Directive (European Council 2014). Therefore, the dewatering of coal mines will require a decision by the National Atomic Energy Agency for a method to solve the problem. Radiation hazards to inhabitants of the Upper Silesia region are another issue. In our experience, the most likely pathway of this hazard is external radiation from the sediments because this water is unsuitable for drinking due to its salinity. However, these sediments are typically covered by water (brooks and rivers) and may sometimes appear on river banks due to floods or the dredging of watercourses. We estimate that additional doses for inhabitants should not exceed $0.1 \mathrm{mSv} /$ year, which is well below the $1 \mathrm{mSv} /$ year threshold (Skubacz et al. 1992; Michalik 2008, 2011). Nonetheless, due to the long halflives of radium isotopes, particularly ${ }^{226} \mathrm{Ra}$, the deposition of 
radium on the river beds and contamination of adjacent areas by released brines is, in our opinion, an important environmental problem in the USCB (Chałupnik et al. 2017).

\section{Conclusions}

The results of long-term monitoring of radium activity in Polish collieries have shown that overall radium activity being discharged from coal mines have decreased during the last two decades. Nonetheless, the release of underground water from the mines with high radium isotope concentrations may lead to considerably increased radioactivity in the environment.

In 1995 , the maximum ${ }^{226} \mathrm{Ra}$ concentration was as high as $25 \mathrm{~Bq} / \mathrm{L}$, while for ${ }^{228} \mathrm{Ra}$ it was about $13 \mathrm{~Bq} / \mathrm{L}$. In 2016, the maximum concentration of ${ }^{226} \mathrm{Ra}$ was up to $7 \mathrm{~Bq} / \mathrm{L}$, while for ${ }^{228} \mathrm{Ra}$ it was about $10 \mathrm{~Bq} / \mathrm{L}$ (maximum total activity $17 \mathrm{~Bq} / \mathrm{L}$ ). The approximate calculated activity of ${ }^{226} \mathrm{Ra}$ in water flowing into the USCB mines in 2016 reached $483 \mathrm{MBq} /$ day $\left(176 \mathrm{GBq} /\right.$ year), while ${ }^{228} \mathrm{Ra}$ was approximately $715 \mathrm{MBq}$ /day (260 GBq/year). A comparison of assessments conducted in 1995 and 2016 shows that the activity of ${ }^{226} \mathrm{Ra}$ in daily inflows was about $30 \%$ less in 2016 than in 1995, while the activity of ${ }^{228} \mathrm{Ra}$ was comparable in both years. The reasons for the changes in the ${ }^{226} \mathrm{Ra} /{ }^{228} \mathrm{Ra}$ ratio of formation waters are complex, and include changes in the geological conditions at the mine's deeper horizons and technical measures due to the restructuring of the mining industry.

The radium concentrations in the mine water discharges were, and are still, enhanced. Due to dilution, there is a significant decrease in radium concentrations, especially in big rivers like Vistula. On the other hand, during seasons with low precipitation, the enhanced radium activity can be seen few dozens or even $100 \mathrm{~km}$ downstream from the mines' discharges.

Radium is gradually removed from river water by adsorption onto bottom sediments. Although the impact of radiumbearing water from the Upper Silesian coal mines on river water and bottom sediments is clear, the radiation doses received by inhabitants were low. Evaluations conducted by scientists from Central Mining Institute showed that annual doses received from wastewater with enhanced radioactivity and the presence of radionuclides in waste rocks released by the mines are well below the $1 \mathrm{mSv}$ threshold.

A comparison of radium activity in inflows and discharges from collieries in 1995 and 2016 showed that even though roughly $50 \%$ of the coal mines in the USCB closed over the last two decades, and radium removal techniques have been applied in underground galleries, only a $20 \%$ decrease of total radium activity has been observed in colliery inflows and mine effluents. This is because of deeper exploitation in active mines and the fact that water from abandoned mines that are adjacent to active ones, must still be pumped out. Thus, it remains an important environmental problem in the USCB in Poland.

Acknowledgements This work was supported by the Polish Ministry of Science and Higher Education within the statutory activity of the Central Mining Institute, contract 11310255-370. The authors acknowledge the contribution of the 7. PR EURATOM project: Coordination and implementation of a pan-European instrument for radioecology (project 604974, project acronym: COMET).

Open Access This article is distributed under the terms of the Creative Commons Attribution 4.0 International License (http://creativeco mmons.org/licenses/by/4.0/), which permits unrestricted use, distribution, and reproduction in any medium, provided you give appropriate credit to the original author(s) and the source, provide a link to the Creative Commons license, and indicate if changes were made.

\section{References}

Alley B, Beebe A, Rodgers J Jr, Castle JW (2011) Chemical and physical characterization of produced waters from conventional and unconventional fossil fuel resources. Chemosphere 85(1):74-82. https://doi.org/10.1016/j.chemosphere.2011.05.043

Bondaruk J, Janson E, Wysocka M, Chałupnik S (2015) Identification of hazards for water environment in the Upper Silesian coal basin caused by the discharge of salt mine water containing particularly harmful substances and radionuclides. J Sustain Min 14(4):179187. https://doi.org/10.1016/j.jsm.2016.01.00.1

Bukowski P (2015) Evaluation of water hazard in hard coal mines in changing conditions of functioning of mining industry in Upper Silesian Coal Basin-USCB (Poland). Arch Min Sci 60(2):65485. https://doi.org/10.1515/amsc-2015-0030

Bukowski P, Augustyniak I (2013) Changes in the structure of water inflow into coal mines in Poland. Proc, 13th Interdisciplinary Scientific GeoConf (SGEM), vol II. Albena, Bulgaria, 16.0622.06, pp 25-32. https://doi.org/10.5593/SGEM2013/BA1.V2/ S02.004

Buła Z, Kotas A (1994) Geological Atlas of Upper Silesian Coal Basin, Part III, Structural Geological Maps. Polish Geological Institute, Warszawa

Centeno LM, Faure G, Lee G, Talnagi J (2004) Fractionation of chemical elements including the REEs and ${ }^{226} \mathrm{Ra}$ in stream contaminated with coalmine effluent. Appl Geochem 19:1085-1095. https://doi. org/10.1016/j.apgeochem.2004.01.008

Chałupnik S (2007) Radium in waters of Upper Silesian collieries, methods of monitoring, the environmental impact assessment, mitigation of pollution. Disse, CentralMining Institute, Katowice (in Polish)

Chałupnik S (2008) Radium transfer from solid into liquid phase. A theoretical approach to its behaviour in aquifers. Proc, 5th international conf on uranium mining and hydrogeology, freiberg, uranium, mining and hydrogeology, pp 851-864

Chałupnik S, Lebecka J (1992) Determination of ${ }^{226} \mathrm{Ra},{ }^{228} \mathrm{Ra}$ and ${ }^{224} \mathrm{Ra}$ in water and aqueous solutions by liquid scintillation counting. In: Noakes E, Schonhofer F, Polach HA (eds) Proc, international conf on advances in LSC 92, Vienna, Austria. Radiocarbon, Tucson, pp 397-403

Chałupnik S, Michalik B, Wysocka M, Skubacz K, Mielnikow A (2001) Contamination of settling ponds and rivers as a result of discharge of radium-bearing waters from Polish coal mines. 
J Environ Radioact 54(1):85-98. https://doi.org/10.1016/S0265 -931X(00)00168-5

Chałupnik S, Wysocka M, Janson E, Chmielewska I, Wiesner M (2017) Long term changes in the concentration of radium in discharge waters of coal mines and Upper Silesian rivers. J Environ Radioact 171:117-123. https://doi.org/10.1016/j.jenvrad.2017.02.007

Dickson BL (1990) The environmental behaviour of radium. Technical Report STI/DOC/10/310, Radium in Groundwater, IAEA, Vienna

Dubiński J (2013) Sustainable development of mining mineral resources. J Sustain Min 12(1):1-6. https://doi.org/10.7424/jsm13 0102

Eggeling L, Genterb A, Kölbela T, Münch W (2013) Impact of natural radionuclides on geothermal exploitation in the Upper Rhine Graben. Geothermics 47:80-88. https://doi.org/10.1016/j.geoth ermics.2013.03.002

Eriksen DØ, Sidhu R, Ramsøy T, Strålberg E, Iden KI, Rye H (2009) Radioactivity in produced water from Norwegian oil and gas installations - concentrations, bioavailability, and doses to marine biota. Radioprotection 44:869-874. https://doi.org/10.1051/radio pro/20095155

European Council (2014) Council Directive 2013/59/EURATOM of 5 December 2013 laying down basic safety standards for protection against the dangers arising from exposure to ionising radiation and repealing Directives 89/618/Euratom, 90/641/Euratom, 96/29/ Euratom, 97/43/Euratom and 2003/122/Euratom. Official Journal of the European Union, 17.1.2014., L 13/1-L 13/73

Galhardi JA, Bonotto DM (2017) Radionuclides $\left({ }^{222} \mathrm{Rn},{ }^{226} \mathrm{Ra},{ }^{234} \mathrm{U}\right.$, and ${ }^{238} \mathrm{U}$ ) release in natural waters affected by coal mining activities in southern Brazil. Water Air Soil Pollut 228:207. https://doi. org/10.1007/s11270-017-3381-x

Gans I, Fuhrmann D, Weller E, Wollenhaupt H (1981) Radium in waste water from coal mines and other sources in FRG. Proc, 2nd special symp on natural radiation environment. Bhabha Atomic Research Centre, Bombay

Gucało LK (1964) O niekotorych zakonomiernostiach raspredielenija radia w podziemnych wodach sredniej czasti DnieprowskoDonieckoj Wpadliny. Gieochimja 12:1305-1312 (in Russian)

Gzyl G, Janson E, Łabaj P (2017) Mine water discharges in Upper Silesian Coal Basin Poland. In: Bech J, Bini C, Pashkevich MA (eds) Restoration and reclamation of mining influenced soils, Academic Press. ISBN 0128097299

Khademi A, Alemi AA, Nasseri A (1980) Transfer of radium of soil to plants in an area of high natural radioactivity in Ramsar, Iran. Proc, conference on natural radiation environment III, Bethesda, Maryland, USA, CONF-780422, T.I:600

Koster HW, Marwitz PA, Berger GW, van Weeres A, Hagel P, Nieuwenhuize $\mathrm{J}(1992){ }^{210} \mathrm{Po},{ }^{210} \mathrm{~Pb},{ }^{226} \mathrm{Ra}$ in aquatic ecosystems and polders, anthropogenic sources, distribution and enhanced radiation doses in the Netherlands. Radiat Prot Dosimetry 45:715-719

Kotas A (1982) The outline of geological structure of Upper Silesian Coal Basin. Proc, 54th Meeting of Polish Geological Society, Wyd Geol Warszawa (in Polish)

Krishnaswami S, Turekian KK (1982) U-238, Ra-226 and Pb-210 in some vent waters of the Galapagos spreading center. Geophys Res Lett 9:827-830

Krishnaswami S, Turekian KK, Graustein WC, Dowd JF (1982) Radium, thorium and radioactive lead isotopes in groundwater. Water Resour Res 18:1663-1675

Martin R, Akber RA (1999) Radium isotopes as indicator of adsorption-desorption interactions and barite formation in groundwater. J Environ Radioact 46(3):271-286
Michalik B (2004) The assessment of exposure to ionizing radiation at spoil banks. Proc, international conf on Naturally Occurring Radioactive Materials (NORM IV) held in Szczyrk, Poland, IAEA-TECDOC-1472, pp 104-116

Michalik B (2008) NORM impacts on the environment: an approach to complete environmental risk assessment using the example of areas contaminated due to mining activity. Appl Radiat Isot 66:1661-1665. https://doi.org/10.1016/j.apradiso.2008.01.025

Michalik B (2011) Radioactive contamination of the environment, caused by underground mining. Diss, Central Mining Institute, Katowice (in Polish)

Paschoa AS, Nobrega AW (1981) Non-nuclear mining with radiological implications in Araxa. In: Gomez M (ed) Radiation hazards in mining. Kingsport Press Inc, Kingsport

Różkowski A (1995) Factors controlling the groundwater conditions of the Carboniferous strata in the Upper Silesian Coal Basin, Poland. Ann Soc Geol Pol 64:53-66

Różkowski A, Wilk Z (1982) Hydrological problems of Upper Silesian Coal Basin and its northern periphery. Proc,LVI Conf of Polish Geological Soc, Sosnowiec, Poland, pp 72-89 (in Polish)

Sałdan M (1965) Metalogenesis of uranium in Carboniferous strata of Upper Silesian Coal Basin, (Metalogeneza uranu w utworach karbońskich Górnośląskiego Zagłębia Węglowego). Biul Inst Geol 193:111-169 (in Polish)

Skowronek J, Skubacz K, Michalik B, Mielnikow A (1998) Radiation hazard in Polish coal mines 1997. In: Konopko W (ed) Annual report of natural and technical hazards in hard coal mining. Central Mining Institute, Katowice, pp 112-133 (in Polish)

Skubacz K, Lebecka J, Chałupnik S, Wysocka M (1992) Possible changes in radiation background of the natural environment caused by coal mines activity. Energy Sources 14(2):149-153. https://doi.org/10.1080/00908319208908716

Sohrabi M (1993) High level natural radiation areas with special regard to Ramsar. In: Furlan G, Romassino L (eds) Proceedings of the second workshop on radon monitoring in radioprotection, environmental and/or earth science. World Scientific, Singapore, pp 98-108

Tomza I, Lebecka J (1981) Radium bearing waters in coal mines. Proc, international conf on radiation hazard in mining, Golden, $\mathrm{CO}$, USA

Tomza I, Lebecka J, Pluta I (1986) Radioactivity of waters occurring in carboniferous strata in Upper Silesian Coal Basin In: Reports of Central Mining Institute, Katowice (in Polish)

Vesterbacka P (2007) Natural radioactivity in drinking water in Finland. Boreal Environ Res 12:11-16

Wagner J (1996) Hydrogeological features of deep Carboniferous strata in Main Syncline of Upper Silesian Coal Basin. Diss, Polish Geological Institute, Sosnowiec (in Polish)

Wardaszko T, Radwan I, Pietrzak-Flis Z (2001) Radioactive contamination of rivers and lakes in Poland in 1994-2000. Biblioteka Monitoringu Środowiska, Warszawa

Wiegand JW, Feige S (2002) Origin of radium in highly mineralized waters. Technical Report IAEA-TECDOC-1271, Vienna

Wysocka M, Skowronek J (1991) Analysis of the natural radioactivity of coal from the Upper Silesian Coal Basin. Proc, internat symp on nuclear techniques in the exploration and exploitation of energy and mineral resources. IAEA-SM-308/74, Vienna

Wysocka M, Skubacz K, Chałupnik S, Samolej K, Bonczyk M, Chmielewska I (2017) Radiation hazard in Polish coal mines, 2016. In: Kabiesz J, Patyńska R (eds) Annual report of natural and technical hazards in hard coal mining. Central Mining Institute, Katowice, pp 110-125 (in Polish) 